\title{
Regulation of cell polarity by controlled proteolytic systems
}

\author{
Daniel A Bórquez and Christian González-Billault* \\ Laboratory of Cell and Neuronal Dynamics, (1) Department of Biology and (2) Institute for Cell Dynamics and Biotechnology (ICDB), \\ Faculty of Sciences, Universidad de Chile.
}

\begin{abstract}
Epithelial and neuronal cells are highly asymmetric, with discrete regions responsible for different roles that underlie the generation of specific compartments within cells that are distinct in biochemical composition, structure, and morphology that ultimately lead to distinct functions. Controlled and specific molecular targeting and sorting have been studied to understand the generation of asymmetric domains inside cells. Recently, a new and complementary explanation has emerged to account for the generation of domains that are enriched by a subset of proteins or polarization determinants: local proteolysis. In this review, we discuss the most conspicuous proteolytic systems that may contribute to the generation of cell polarity, namely the ubiquitin-proteosome and the calpain systems. Specifically, we focus this review on two cellular processes that depend on the acquisition of cell polarity; cell migration and the establishment of an axon in a neuronal cell.
\end{abstract}

Key terms: calpain, neuronal polarity, proteolytic systems, ubiquitin proteasome.

\section{INTRODUCTION}

Cellular asymmetry is a central event in several physiological processes, including directed cell migration and the determination of morphology in neurons. In spite of molecular differences among them, migrating cells and differentiating neurons behave as polarized structures. Migrating cells display two polarized protrusions, the leading and trailing edges, that extend from the cell body (Petrie et al., 2009). Differentiating neurons include two polarized domains that differ in composition and function, the axon and the somatodendritic compartment. In both cases, the acquisition of polarity is a central issue associated with the enrichment of a subset of proteins in a particular cellular compartment. Most efforts have been directed at understanding polarized molecular sorting as the main mechanism underlying the differential accumulation of a limiting factor in a polarized cell (Bradke and Dotti, 1997). More recently, the concept has emerged of spatially restricted protein degradation as an alternative and complementary mechanism responsible for the enrichment of polarizing factors (Perrin et al., 2006; Schwamborn et al., 2007b; Wang et al., 2003; Yan et al., 2006). This review focuses on two of the most conspicuous proteolytic systems in cells, the calpain and ubiquitin proteasome systems, and their roles in the acquisition of polarity of both migrating cells and neurons.

Regulatory role of cellular proteases

For many years, protein degradation was considered a nonspecific process responsible for protein turnover. However, the discovery in recent decades of intricate mechanisms that regulate the ubiquitin proteasome system and the calpains has unraveled new and emerging roles for protein degradation that are linked to the control of many processes. For example, these proteolytic systems may be involved in cellular proliferation (Sato and Kawashima, 2001), cellular differentiation (Yajima and Kawashima, 2002), epithelial and neuronal migration (Franco and Huttenlocher, 2005), the development of cell polarity (Miyazaki et al., 2007), and cell death (Harwood et al., 2005).

Ubiquitin conjugation is initiated by the binding of a small protein of 76 amino acids to the lysine residues of a protein substrate through a multistep process involving three different types of enzymes: a ubiquitin-activating enzyme (E1), a ubiquitin-conjugating enzyme (E2), and a ubiquitin-protein ligase (E3). The ubiquitin ligase determines the specificity of the reaction through the formation of a multiprotein complex involving the E2 enzyme and the substrate (Ye and Rape, 2009).

Polyubiquitine-conjugated proteins are destined to the $26 \mathrm{~S}$ proteasome, an eukaryotic ATP-dependent protease. This large multiprotein complex consists of two parts: the catalytic $20 S$ proteasome and the regulatory particle 19S, each composed of an array of multiple subunits. The regulatory particle is responsible for recognizing ubiquitinated proteins, promoting their unfolding and allowing access to the catalytic core. The $20 \mathrm{~S}$ proteasome has a barrel shape formed by four rings of seven subunits each. The two central $\beta$ rings possess catalytic activities oriented inside the proteolytic chamber, while the two $\alpha$ rings attach the regulatory subunit 195 to the 205 proteasome (Glickman and Ciechanover, 2002).

The calpain family of cysteine proteases is comprised of 14 isoforms in mammals, all of which are activated by calcium. Some isoforms are ubiquitously distributed in most tissues, such as calpains 1 and 2, whereas other isoforms have a more restricted pattern of expression. The regulation of calpain activity depends on changes in intracellular concentrations of calcium. Calpain 2, one of the main isoforms found in most tissues, requires millimolar concentrations of calcium to be activated in vitro. Because millimolar concentrations of calcium may be considered well beyond physiological levels under most conditions, calpain activity has traditionally been linked to pathological events and cell death (Friedrich, 2004).

\footnotetext{
* Corresponding author: Christian Gónzalez-Billault, Laboratory of Cell and Neuronal Dynamics, Department of Biology and Institute for Cell Dynamics and Biotechnology (ICDB), Faculty of Sciences Universidad de Chile, Las Palmeras 3425, Ñuñoa, Santiago, Chile. Phone: +56-2-9787442, Fax: +56-2-2712983, E-mail: chrgonza@uchile.cl
} 
A role for calpain isoforms in cellular signaling was suggested with the discovery that multiple mechanisms in vivo may severely reduce or even replace the dependence on high calcium levels needed for protease activation. Among these mechanisms are calpain binding to lipids (Arthur and Crawford, 1996; Chakrabarti et al., 1996), autolysis (Li et al., 2004), phosphorylation (Glading et al., 2004), and sumoylation (Wang et al., 2009).

Unlike the ubiquitin proteasome system, calpains do not lead to extensive degradation of their substrates, but rather generate stable fragments through a restricted number of proteolytic cuts. These fragments have functions that are distinct from those of the intact protein. The diversity of newly discovered functions of calpains is closely related to the discovery of more than 150 calpain substrates that include transcription factors (Oda et al., 2002), transmembrane receptors (Simpkins et al., 2003; Struewing et al., 2007; Xu et al., 2007), signaling enzymes (Shioda et al., 2006; Tremper-Wells and Vallano, 2005), and cytoskeletal proteins (Cortesio et al., 2010; Yamada et al., 2009). These substrates indicate that cell proteases may have multiple regulatory roles. This article will discuss the regulatory roles of proteases in the determination of cellular polarity in cell migration and neuronal polarization.

Role of calpain in polarization during cell migration

Chemotaxis is a highly specialized form of cell migration in which cell movements and changes in polarity are instructed by specific chemical cues, which are often presented as an extracellular gradient (Devreotes and Janetopoulos, 2003). This process is essential for the rapid recruitment of neutrophils to sites of infection through a mechanism that is dependent on the secretion of chemokines by endogenous cells of the infected tissue or by infiltrating leukocytes. During neutrophil migration, actin microfilament polymerization leads to the extension of membrane projections (i.e., protrusions) at the leading edge, including filopodia and lamellipodia, which are required for directional migration. In the case of neutrophils, exposure to a chemoattractant gradient induces the rapid enrichment of the protease calpain 2 at the leading edge where it colocalizes with F-actin (Nuzzi et al., 2007). Localization of the protease at the leading edge seems to be causal for neutrophil migration because the expression of an inactive protease variant (Calpain PD) generates multiple lamellipodia surrounding neutrophils without a defined leading edge and prevents efficient chemotaxis (Nuzzi et al., 2007).

Calpain 2 also plays a role in the control of the dynamics of the lamellipodia in fibroblasts. Lamellipodial protrusions are produced by the polymerization of branched-actin filaments adjacent to the plasma membrane. The actin regulatory protein cortactin, which is involved in the formation of membrane protrusions, is a substrate of calpains and a major downstream target for calpain 2 in particular (Table I). Knock down of calpain 2 by siRNA results in an increase in both the speed and frequency of the occurrence of the protrusion and retraction events at the membrane (Franco et al., 2004). Overexpression of a proteolysis-resistant form of cortactin results in defects similar to those observed in calpain 2 knockdown cells (Perrin et al., 2006).

Role of the ubiquitin proteasome system in protrusive activity during cell migration

The ubiquitin proteasome system also plays a role in cell migration, particularly during the process of cell protrusion. Protrusion is the process during which plasmatic membranes extend in order to favor cell movements. Smad ubiquitination regulatory factor (Smurf)-1 is an E3 ubiquitin ligase from the C2-WW-Hect family, controlling the assembly/disassembly of focal adhesions, that contributes to regulate cell migration. Talin is a key molecule involved in integrin activation and focal adhesion formation (Huang et al., 2009). Talin is proteolyzed by calpain 2, and the fragment generated is subsequently tagged by Smurf-1 for proteasome degradation (Huang et al., 2009). Smurf1 is recruited to protrusive regions through its interaction with protein kinase C (PKC)- $\zeta$, which induces the ubiquitination and degradation of the inactive form of RhoA (Table I). Overexpression of Smurf1 leads to

\section{Table I}

Proteins involved in cell polarity that are targets of proteolytic systems

\begin{tabular}{|c|c|c|c|}
\hline Protein (function) & $\begin{array}{l}\text { Protease involved } \\
\text { in its degradation }\end{array}$ & Proteolytic regulatory mechanisms & References \\
\hline $\begin{array}{l}\text { Akt (mediates signals } \\
\text { from growth factors) }\end{array}$ & Proteasome & $\begin{array}{l}\text { The inactive form in the somatodendritic compartment is } \\
\text { degraded during the development of neuronal polarity. }\end{array}$ & (Yan et al., 2006) \\
\hline $\begin{array}{l}\text { Rap1B } \\
\text { (small GTPase) }\end{array}$ & Proteasome & $\begin{array}{l}\text { The GDP form (inactive) is conjugated with ubiquitin by Smurf2, } \\
\text { which restricts the active form (GTP bound) to the tip of the } \\
\text { putative axon. }\end{array}$ & $\begin{array}{l}\text { (Schwamborn et al., } \\
\text { 2007) }\end{array}$ \\
\hline $\begin{array}{l}\text { RhoA } \\
\text { (small GTPase) }\end{array}$ & $\begin{array}{l}\text { Proteasome and } \\
\text { calpain }\end{array}$ & $\begin{array}{l}\text { Smurf1- and calpain-mediated RhoA inactivation prevents stress } \\
\text { fiber formation in protrusive regions with high Cdc } 42 \text { and Rac1 } \\
\text { activity. }\end{array}$ & $\begin{array}{l}\text { (Bryan et al., 2005; } \\
\text { Kulkarni et al., 2002; } \\
\text { Wang et al., 2003) }\end{array}$ \\
\hline $\begin{array}{l}\text { Cortactin } \\
\text { (actin regulatory } \\
\text { protein) }\end{array}$ & Calpain & $\begin{array}{l}\text { Proteolysis of cortactin regulates axon branching in neurons and } \\
\text { membrane protrusion in migrating cells. }\end{array}$ & $\begin{array}{l}\text { (Mingorance-Le Meur } \\
\text { and O'Connor, 2009; } \\
\text { Perrin et al., 2006) }\end{array}$ \\
\hline LIMK1 & Proteasome & $\begin{array}{l}\text { The ubiquitin ligase Rnf6 allows degradation of LIMK1 on the } \\
\text { growth cone, thus facilitating axonal growth. }\end{array}$ & (Tursun et al., 2005) \\
\hline
\end{tabular}


increased numbers of protrusions at the leading edge and disrupts fibroblast polarity (Wang et al., 2003). Thus, Smurf1 prevents the formation of stress fibers during the dynamic remodeling of actin, which then elicits the rapid formation of lamellipodial and filopodial extensions (Wang et al., 2003). A similar mechanism of proteolytic regulation is also observed in neuronal cells where Smurf1 overexpression promotes the growth of neurites (Bryan et al., 2005). The mechanism is slightly different in peripheral nervous system neurons, where Smurf1 influences axonal growth but not the development of polarity (Vohra et al., 2007). However, in a recent study, Yi et al, showed the importance of the type II receptor of transforming growth factor (TGF)- $\beta$ in determining neuronal polarity through phosphorylation of Par6 (Yi et al., 2010). Par6 phosphorylation was shown to be important for the establishment of polarity in epithelial cells, by favoring the interaction of Par6 with Smurf1, and the subsequent ubiquitin tagging and degradation of RhoA (Ozdamar et al., 2005), opening the possibility that a similar mechanism could operate in central nervous system neurons. Another isoform of this ubiquitin ligase, Smurf2, has a role in cell polarity, which will be discussed in the next section.

Role of protein degradation in the establishment of neuronal polarity

The development of neuronal polarity has classically been studied in cultured rat hippocampal neurons in which discrete stages can be distinguished during axonal development. In stage 1 , recently adhered neurons display active lamellipodial and filopodial protrusive activity. This increased actin-dependent protrusive activity is then followed by the formation of multiple immature neurites, which are continuously extending and retracting, leading to an essentially symmetrical cell (stage 2). The breakdown of this symmetry occurs when one of these neurites begins to extend more quickly than its sibling neurites and then becomes the axon (stage 3). The remaining minor neurites develop further into dendrites (stages 4 and 5) (Tahirovic and Bradke, 2009).

During stage 2, when neurons are morphologically symmetrical, the molecular determinants that drive extension of the axon begin to locally accumulate in the minor neurite that will later become the axon. The growth cone of prospective axons is characterized by high instability of the actin cytoskeleton (Bradke and Dotti, 1999). The accumulation of these molecular determinants is very similar to what occurs at the leading edge of migrating cells. Therefore, it is not surprising that many of the molecular mechanisms governing the development of neuronal polarity have a correlate in the development of polarity during directed cell migration.

At the beginning of stage 3 , the accumulation of phosphatidylinositol $(3,4,5)$-trisphosphate (PIP3) in the prospective axonal membrane is the earliest molecular event leading up to axonal elongation (Menager et al., 2004). PIP3 accumulation is primarily generated by phosphatidylinositol3-kinase (PI3K) activity, which itself is activated by the binding of growth factors to its receptor tyrosine kinase (Shi et al., 2003; Sosa et al., 2006). This generates a powerful positive feedback loop with the small GTPase Ras, which eventually leads to the breakdown of morphological symmetry (Fivaz et al., 2008).

Increased PI3K activity also leads to the activation of other small GTPases, such as Rap1b and subsequently Cdc42 (Schwamborn and Puschel, 2004), and enhances PIP3 levels in the plasma membrane, which leads to further recruitment and activation of the protein kinase Akt (Menager et al., 2004; Shi et al., 2003). Additionally, the selective degradation of the inactive pools of Akt and Rap1B may contribute to the local enrichment of these signaling proteins (Table I). The activation of Akt in the axonal growth cones of polarized neurons is controlled by selective activation with increased PIP3 in the plasma membrane, and also by selective degradation of inactive Akt in minor neurites (Yan et al., 2006).

Smurf2, a ubiquitin ligase, plays an important role in the regulation of axonal elongation and polarity. Rap1B is also found in the nascent axonal tip, and its overexpression leads to multi-axonal hippocampal neurons. In contrast, Rap1B loss of function mediated by the use of siRNA prevents the formation of axons, a phenotype that is rescued by the expression of a constitutively active form of Cdc42. Because a loss-of-function mutation in Cdc42 cannot be rescued by constitutively active forms of Rap1B, the latter should be located upstream of Cdc42. Moreover, constitutively active versions of both Cdc42 and Rap1B, GTPases reverse the inhibition of axonal elongation that occurs after pharmacological inhibition of PI3K activity. Like Akt, Rap1B is concentrated in a single neurite by the selective degradation of the inactive protein in those neurites that will give rise to dendrites. This degradation is mediated by the ubiquitin ligase activity of Smurf2 (Schwamborn et al., 2007b). Smurf2 is directed toward the axonal growth cone through the interaction of its HECT domain with the third PDZ domain of the scaffold polarity protein Par3, which allows their transport by coupling the KIF3A subunit of kinesin-2 (Schwamborn et al., 2007a).

Cdc42 activation had been linked to Rac1 activation through a Par3-Par6-aPKC mechanism (Nishimura et al., 2005). Interestingly, Par3 is able to interact directly with the invasion-inducing T-lymphoma and metastasis (Tiam)1 protein (Table II), which is a specific activator for Rac (Michiels et al., 1995). Tiam1 has been proposed to participate in the determination of polarity in neurons (Kunda et al., 2001), the control of migrating cells (Pegtel et al., 2007), and the acquisition of T-cell (Gerard et al., 2007) and epithelial cell (Chen and Macara, 2005) polarity. Src-phosphorylated Tiam1 may be proteolyzed by calpain, generating a Tiam1-inactive fragment that induces the disassembly of adheren junctions in epithelial cells (Woodcock et al., 2009), and therefore may play a role in the determination of polarity in these cells. Par3 also interacts with other components of the proteasome in epithelial cells, including its activators PA28 $\beta$ and PA28 $\gamma$, although the significance of these interactions has not yet been determined (Zhou et al., 2008).

Akt activation also induces glycogen synthase kinase (GSK)-3 $\beta$ (Table II) inactivation, leading to decreased phosphorylation of collapsin response mediator protein (CRMP)-2 (Table II) in Thr514 (Yoshimura et al., 2005). Although initially described as a regulator of glycogen metabolism, GSK3 $\beta$ is also involved in regulating the acquisition of cell polarity in multiple processes and cell types, including directed cell migration (Etienne-Manneville and Hall, 2003), axon specification (Jiang et al., 2005), and apicalbasal polarity in epithelia (Colosimo et al., 2010). Calpain cuts the N-terminal segment of GSK3 $\beta$, which generates the constitutively active kinase (Goni-Oliver et al., 2007), and is thus an alternative mechanism for controlling GSK3 $\beta$ activation. 
Table 2

Putative roles of protein degradation in the regulation of neuronal cell polarity

\begin{tabular}{|c|c|c|c|}
\hline Protein (function) & $\begin{array}{l}\text { Protease involved } \\
\text { in its degradation }\end{array}$ & Proteolytic regulatory mechanisms & References \\
\hline $\begin{array}{l}\text { GSK3 } \beta \text { (regulator of } \\
\text { glycogen synthesis) }\end{array}$ & Calpain & $\begin{array}{l}\text { Calpain proteolyzes and activates GSK3 } \beta \text {, an important } \\
\text { regulator of cell polarity. }\end{array}$ & $\begin{array}{l}\text { (Goni-Oliver et al., 2007; Shi } \\
\text { et al., 2004) }\end{array}$ \\
\hline $\begin{array}{l}\text { Kidins } 220 / \text { ARMS } \\
\text { (scaffold protein) }\end{array}$ & Calpain & $\begin{array}{l}\text { Calpain proteolysis of Kidins } 220 \text { / ARMS may regulate its } \\
\text { effect on axonal extension in neurons. }\end{array}$ & $\begin{array}{l}\text { (Higuero et al., 2010; Lopez- } \\
\text { Menendez et al., 2009) }\end{array}$ \\
\hline $\begin{array}{l}\text { CRMP2 (mediator } \\
\text { of semaphorin } 3 \mathrm{~A} \\
\text { signaling; tubulin GAP }\end{array}$ & Calpain & $\begin{array}{l}\text { Calpain proteolysis of the N-terminal region of CRMP-2 } \\
\text { may regulate tubulin GTPase functions of CRMP- } 2 \text { and } \\
\text { result in the induction of multiple axons in neurons. }\end{array}$ & $\begin{array}{l}\text { (Chae et al., 2009; Inagaki et } \\
\text { al., 2001; Liu et al., 2009) }\end{array}$ \\
\hline hPEM2 (Cdc42 GEF) & Proteasome & $\begin{array}{l}\text { Smurf1 induces proteosomal degradation of hPEM-2, } \\
\text { possibly regulating Cdc42 activity in cell polarity. }\end{array}$ & (Yamaguchi et al., 2008) \\
\hline Tiam1 (Rac1 GEF) & Calpain & $\begin{array}{l}\text { ERK phosphorylation induces local calpain-mediated } \\
\text { degradation of Tiam1, an essential regulator of axonal } \\
\text { extension. }\end{array}$ & $\begin{array}{l}\text { (Kunda et al., 2001; } \\
\text { Woodcock et al., 2009) }\end{array}$ \\
\hline
\end{tabular}

CRMP2 was originally characterized as a protein that mediates growth cone collapse in response to semaphorins (Goshima et al., 1995). Overexpression of CRMP2 in neurons induces the generation of multiple axons (Inagaki et al., 2001), partly because of its activity as a GTPase-activating protein (GAP) for tubulin, which promotes microtubule polymerization (Chae et al., 2009). Such activity is located at the $\mathrm{C}$ terminus of CRMP2, as a variant that lacks this domain acts as a dominant negative, leading to the formation of neurons that have either one or no axon (Inagaki et al., 2001). Calpains proteolyze the C-terminal region of CRMP2 (Liu et al., 2009) and therefore may act as a physiological regulator of CRMP2 activity and growth cone formation.

Several effector proteins involved in cytoskeleton dynamics and growth cone formation are found downstream of Rap1b and Cdc42 GTPases. These include LIM kinase 1 (LIMK1) and its direct substrate, the actin dynamizing factor cofilin (Garvalov et al., 2007). Overexpression of LIMK1 leads to an increase in axonal length, whereas decreased expression leads to the opposite phenotype (Rosso et al., 2004). Therefore, the regulation of LIMK levels is likely to be important for axonal elongation. The ubiquitin ligase Rnf6 proteolyzes LIMK1, reducing its levels in growth cones. Rnf6 overexpression leads to shorter axons, which is rescued by overexpression of LIMK1, revealing the importance of this mode of regulation in the control of axonal outgrowth (Table I) (Tursun et al., 2005).

Another signaling protein that contributes to the generation of neuronal polarity has been recently described. Kinase D-interacting substrate of $220 \mathrm{kDa}$ (Kidins220), also known as ankyrin repeat-rich membrane spanning (ARMS), is a protein expressed predominantly in neural tissues. Kidins 220 is the first known physiological substrate of protein kinase $\mathrm{D}$ (PKD) and has been shown to have a role in determining neuronal polarity (Higuero et al., 2010). Calpain proteolysis influences Kidins220 functions and thus may also influence neuronal polarity via the PKD pathway (Lopez-Menendez et al., 2009). PKD is likely to influence trafficking of trans Golgi network (TGN)-derived dendritic proteins, as kinase-inactive forms of PKD trigger the delivery of dendritic proteins to the axonal compartment. Therefore, PKD function is linked to the determination of neuronal polarity (Bisbal et al., 2008). A role for PKD in regulating the targeting of Golgi-derived elements to the dendritic compartment has been further substantiated using molecular genetic approaches (Czondor et al., 2009).

Conclusions and future directions

In recent years, experimental evidence has elucidated a role for proteolysis in the control of local concentrations of proteins and thus in the generation of molecular asymmetries in cells. Few proteins have been demonstrated to require proteolytic processing to control cell polarity (Table I). In contrast, numerous proteins are substrates for the proteolytic systems, though it remains to be determined whether proteolysis is relevant to their role in generating neuronal polarity (Table II).

Most of the protease substrates associated with cell polarization have also been proposed to play a role in directed cell migration and axonal specification. There are, however, other cellular processes that are relevant for cell morphological determination and function that may also be dependent on the proteolytic processing of proteins. For example, establishment of the apical-basolateral compartments in epithelia and the determination of planar cell polarity (PCP) in a tissue. Two examples of protease substrates are available to explain the participation of proteases in these processes, namely Scribble (Phua et al., 2009) and Prickle (Narimatsu et al., 2009), and it is likely that novel protease substrates will be identified in future years.

Therefore, local proteolysis of proteins may be a complementary and novel mechanism for regulating both the acquisition of polarity that is required for directed cell migration and the establishment of an axon. This mechanism should thus be conserved across different cell types. Ongoing research to indentify new targets for proteolysis will continue to expand our understanding of the molecular mechanisms governing the migration of cells and the development of neuronal polarity. 


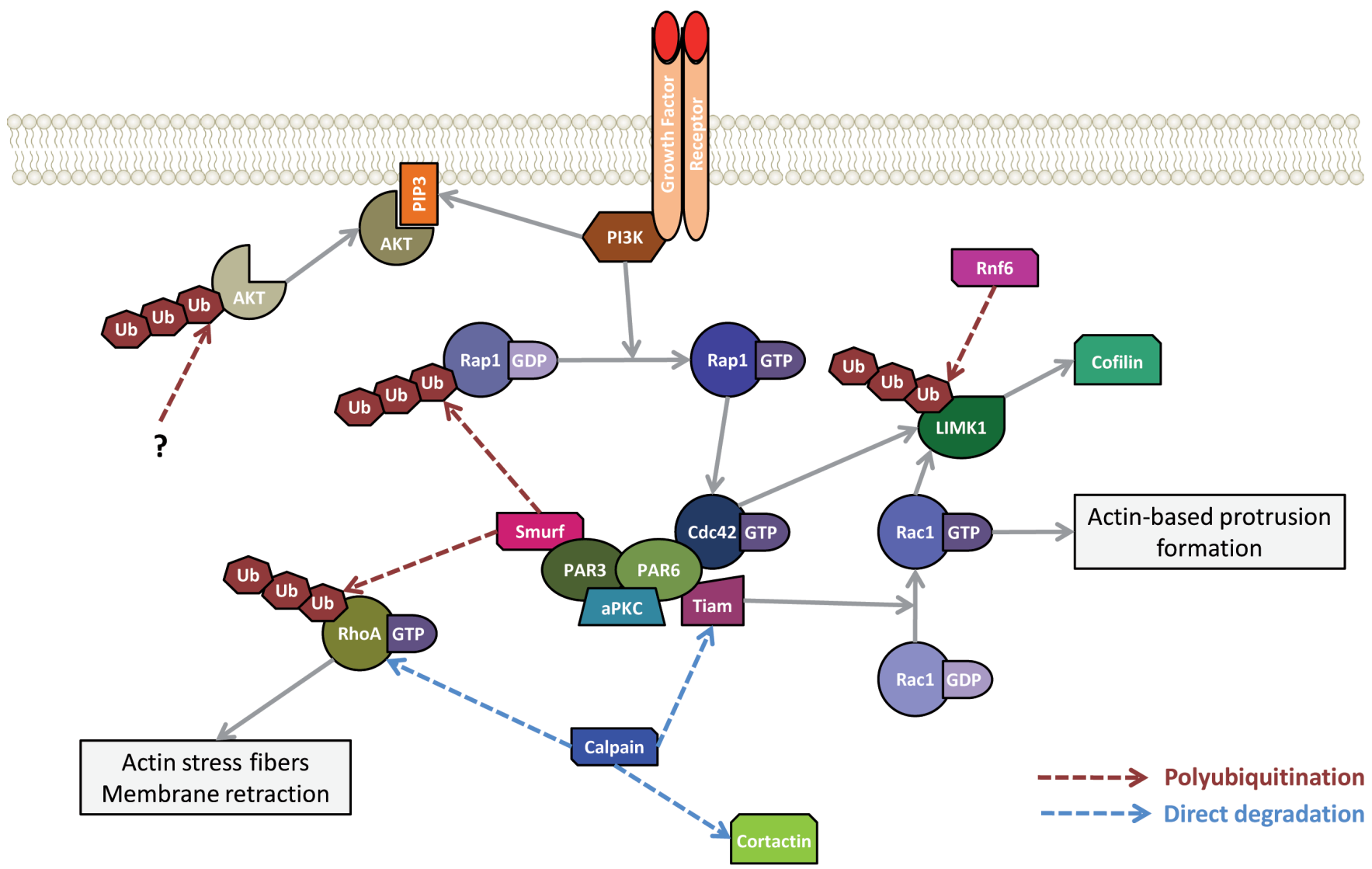

Figure 1. Activation of signaling and structural proteins as a result of calpain proteolysis that are involved in the development of neuronal polarity. The molecular pathway of cell polarity determination begins with the accumulation of PIP3 in the cell protrusive end. This accumulation triggers the sequential activation of GTPases of the Rho family (Rap1, Cdc42, Rac, and Rho itself) that are associated with a polarity supramolecular complex comprising the adapter proteins Par3 and Par6 and members of the atypical PKC family. The proteolytic systems are important checkpoints in the activity of GTPases through the proteolysis of either its inactive form (GDP bound) or its direct regulators ([e.g.,] Tiam1).

\section{ACKNOWLEDGEMENTS}

We acknowledge the following grant support: CONICYT Thesis Support Fellowship D-21070173 and 24090187 (to DB) and grants FONDECYT 1095089 (to CG-B) and ICM P05-001-F (to CG-B).

\section{REFERENCES}

ARTHUR JS, CRAWFORD C (1996) Investigation of the interaction of m-calpain with phospholipids: calpain-phospholipid interactions. Biochim Biophys Acta 1293:201-206.

BISBAL M, CONDE C, DONOSO M, BOLLATI F, SESMA J, QUIROGA S, DIAZ ANEL A, MALHOTRA V, MARZOLO MP, CACERES A (2008) Protein kinase $d$ regulates trafficking of dendritic membrane proteins in developing neurons. J Neurosci 28:9297-9308.

BRADKE F, DOTTI CG (1997) Neuronal polarity: vectorial cytoplasmic flow precedes axon formation. Neuron 19:1175-1186.

BRADKE F, DOTTI CG (1999) The role of local actin instability in axon formation. Science 283:1931-1934.

BRYAN B, CAI Y, WRIGHTON K, WU G, FENG XH, LIU M (2005) Ubiquitination of RhoA by Smurf1 promotes neurite outgrowth. FEBS Lett 579:1015-1019.

COLOSIMO PF, LIU X, KAPLAN NA, TOLWINSKI NS (2010) GSK3beta affects apical-basal polarity and cell-cell adhesion by regulating aPKC levels. Dev Dyn 239:115-125.
CORTESIO CL, PERRIN BJ, BENNIN DA, HUTTENLOCHER A (2010) Actinbinding protein-1 interacts with WASp-interacting protein to regulate growth factor-induced dorsal ruffle formation. Mol Biol Cell 21:186-197.

CZONDOR K, ELLWANGER K, FUCHS YF, LUTZ S, GULYAS M, MANSUY IM, HAUSSER A, PFIZENMAIER K, SCHLETT K (2009) Protein kinase D controls the integrity of Golgi apparatus and the maintenance of dendritic arborization in hippocampal neurons. Mol Biol Cell 20:2108-2120.

CHAE YC, LEE S, HEO K, HA SH, JUNG Y, KIM JH, IHARA Y, SUH PG, RYU SH (2009) Collapsin response mediator protein-2 regulates neurite formation by modulating tubulin GTPase activity. Cell Signal 21:18181826.

CHAKRABARTI AK, DASGUPTA S, GADSDEN RH SR, HOGAN EL, BANIK NL (1996) Regulation of brain m calpain Ca2+ sensitivity by mixtures of membrane lipids: activation at intracellular $\mathrm{Ca} 2+$ level. J Neurosci Res 44:374-380.

CHEN X, MACARA IG (2005) Par-3 controls tight junction assembly through the Rac exchange factor Tiam1. Nat Cell Biol 7:262-269.

DEVREOTES P, JANETOPOULOS C (2003) Eukaryotic chemotaxis: distinctions between directional sensing and polarization. J Biol Chem 278:20445-20448.

ETIENNE-MANNEVILLE S, HALL A (2003) Cdc42 regulates GSK-3beta and adenomatous polyposis coli to control cell polarity. Nature 421:753-756.

FIVAZ M, BANDARA S, INOUE T, MEYER T (2008) Robust neuronal symmetry breaking by Ras-triggered local positive feedback. Curr Biol 18:44-50.

FRANCO S, PERRIN B, HUTTENLOCHER A (2004) Isoform specific function of calpain 2 in regulating membrane protrusion. Exp Cell Res 299:179-187. 
FRANCO SJ, HUTTENLOCHER A (2005) Regulating cell migration: calpains make the cut. J Cell Sci 118:3829-3838.

FRIEDRICH P (2004) The intriguing Ca2+ requirement of calpain activation. Biochem Biophys Res Commun 323:1131-1133.

GARTNER A, HUANG X, HALL A (2006) Neuronal polarity is regulated by glycogen synthase kinase-3 (GSK-3beta) independently of Akt/PKB serine phosphorylation. J Cell Sci 119:3927-3934.

GARVALOV BK, FLYNN KC, NEUKIRCHEN D, MEYN L, TEUSCH N, WU $X$, BRAKEBUSCH C, BAMBURG JR, BRADKE F (2007) Cdc42 regulates cofilin during the establishment of neuronal polarity. J Neurosci 27:13117-13129.

GERARD A, MERTENS AE, VAN DER KAMMEN RA, COLLARD JG (2007) The Par polarity complex regulates Rap1- and chemokine-induced T cell polarization. J Cell Biol 176:863-875.

GLADING A, BODNAR RJ, REYNOLDS IJ, SHIRAHA H, SATISH L, POTTER DA, BLAIR HC, WELLS A (2004) Epidermal growth factor activates m-calpain (calpain II), at least in part, by extracellular signalregulated kinase-mediated phosphorylation. Mol Cell Biol 24:2499-2512.

GLICKMAN MH, CIECHANOVER A (2002) The ubiquitin-proteasome proteolytic pathway: destruction for the sake of construction. Physiol Rev 82:373-428.

GONI-OLIVER P, LUCAS JJ, AVILA J, HERNANDEZ F (2007) N-terminal cleavage of GSK-3 by calpain: a new form of GSK-3 regulation. J Biol Chem 282:22406-22413.

GOSHIMA Y, NAKAMURA F, STRITTMATTER P, STRITTMATTER SM (1995) Collapsin-induced growth cone collapse mediated by an intracellular protein related to UNC-33. Nature 376:509-514.

HARWOOD SM, YAQOOB MM, ALLEN DA (2005) Caspase and calpain function in cell death: bridging the gap between apoptosis and necrosis. Ann Clin Biochem 42:415-431.

HIGUERO AM, SANCHEZ-RUILOBA L, DOGLIO LE, PORTILLO F, ABADRODRIGUEZ J, DOTTI CG, IGLESIAS T (2010) Kidins220/ARMS modulates the activity of microtubule-regulating proteins and controls neuronal polarity and development. J Biol Chem 285:1343-1357.

HUANG C, RAJFUR Z, YOUSEFI N, CHEN Z, JACOBSON K, GINSBERG, MH (2009) Talin phosphorylation by Cdk5 regulates Smurf1-mediated talin head ubiquitylation and cell migration. Nat Cell Biol 11:624-630.

INAGAKI N, CHIHARA K, ARIMURA N, MENAGER C, KAWANO Y, MATSUO N, NISHIMURA T, AMANO M, KAIBUCHI K (2001) CRMP-2 induces axons in cultured hippocampal neurons. Nat Neurosci 4:781-782.

JIANG H, GUO W, LIANG X, RAO Y (2005) Both the establishment and the maintenance of neuronal polarity require active mechanisms: critical roles of GSK-3beta and its upstream regulators. Cell 120:123-135.

KUNDA P, PAGLINI G, QUIROGA S, KOSIK K, CACERES A (2001) Evidence for the involvement of Tiam1 in axon formation. J Neurosci 21:2361-2372.

LI H, THOMPSON VF, GOLL DE (2004) Effects of autolysis on properties of mu- and m-calpain. Biochim Biophys Acta 1691:91-103.

LIU W, ZHOU XW, LIU S, HU K, WANG C, HE Q, LI M (2009) Calpaintruncated CRMP-3 and -4 contribute to potassium deprivation-induced apoptosis of cerebellar granule neurons. Proteomics 9:3712-3728

LOPEZ-MENENDEZ C, GASCON S, SOBRADO M, VIDAURRE OG HIGUERO AM, RODRIGUEZ-PENA A, IGLESIAS T, DIAZ-GUERRA M (2009) Kidins220/ARMS downregulation by excitotoxic activation of NMDARs reveals its involvement in neuronal survival and death pathways. J Cell Sci 122:3554-3565.

MENAGER C, ARIMURA N, FUKATA Y, KAIBUCHI K (2004) PIP3 is involved in neuronal polarization and axon formation. J Neurochem 89:109-118.

MICHIELS F, HABETS GG, STAM JC, VAN DER KAMMEN RA, COLLARD JG (1995) A role for Rac in Tiam1-induced membrane ruffling and invasion. Nature 375:338-340.

MIYAZAKI T, HONDA K, OHATA H (2007) Requirement of Ca2+ influxand phosphatidylinositol 3-kinase-mediated $\mathrm{m}$-calpain activity for shear stress-induced endothelial cell polarity. Am J Physiol Cell Physiol 293:C1216-1225

NARIMATSU M, BOSE R, PYE M, ZHANG L, MILLER B, CHING P, SAKUMA R, LUGA V, RONCARI L, ATTISANO L, WRANA JL (2009) Regulation of planar cell polarity by Smurf ubiquitin ligases. Cell 137:295-307.

NISHIMURA T, YAMAGUCHI T, KATO K, YOSHIZAWA M, NABESHIMA Y, OHNO S, HOSHINO M, KAIBUCHI K (2005) PAR-6-PAR-3 mediates Cdc42-induced Rac activation through the Rac GEFs STEF/Tiam1. Nat Cell Biol 7:270-277.

NUZZI PA, SENETAR MA, HUTTENLOCHER A (2007) Asymmetric localization of calpain 2 during neutrophil chemotaxis. Mol Biol Cell 18:795-805.
ODA A, WAKAO H, FUJITA H (2002) Calpain is a signal transducer and activator of transcription (STAT) 3 and STAT5 protease. Blood 99:18501852.

OZDAMAR B BOSE R BARRIOS-RODILES M., Wang, H.R., Zhang, Y., and Wrana, J.L. (2005). Regulation of the polarity protein Par6 by TGFbeta receptors controls epithelial cell plasticity. Science 307, 1603-1609.

PEGTEL DM, ELLENBROEK SI, MERTENS AE, VAN DER KAMMEN RA, DE ROOIJ J, COLLARD JG (2007) The Par-Tiam1 complex controls persistent migration by stabilizing microtubule-dependent front-rear polarity. Curr Biol 17:1623-1634.

PERRIN BJ, AMANN KJ, HUTTENLOCHER A (2006) Proteolysis of cortactin by calpain regulates membrane protrusion during cell migration. Mol Biol Cell 17, 239-250.

PETRIE RJ, DOYLE AD, YAMADA KM (2009) Random versus directionally persistent cell migration. Nat Rev Mol Cell Biol 10, 538-549.

PHUA DC, HUMBERT PO, HUNZIKER W (2009) Vimentin regulates scribble activity by protecting it from proteasomal degradation. Mol Biol Cell 20:2841-2855.

ROSSO S, BOLLATI F, BISBAL M, PERETTI D, SUMI T, NAKAMURA T, QUIROGA S, FERREIRA A, CACERES A (2004) LIMK1 regulates Golgi dynamics, traffic of Golgi-derived vesicles, and process extension in primary cultured neurons. Mol Biol Cell 15:3433-3449.

SATO K, KAWASHIMA S (2001) Calpain function in the modulation of signal transduction molecules. Biol Chem 382:743-751.

SCHWAMBORN JC, KHAZAEI MR, PUSCHEL AW (2007a) The interaction of mPar3 with the ubiquitin ligase Smurf2 is required for the establishment of neuronal polarity. J Biol Chem 282, 35259-35268.

SCHWAMBORN JC, MULLER M, BECKER AH, PUSCHEL AW (2007b) Ubiquitination of the GTPase Rap1B by the ubiquitin ligase Smurf2 is required for the establishment of neuronal polarity. EMBO J 26:14101422

SCHWAMBORN JC, PUSCHEL AW (2004) The sequential activity of the GTPases Rap1B and Cdc42 determines neuronal polarity. Nat Neurosci 7:923-929.

SHI SH, JAN LY, JAN YN (2003) Hippocampal neuronal polarity specified by spatially localized mPar3/mPar6 and PI 3-kinase activity. Cell 112:63-75.

SHIODA N, MORIGUCHI S, SHIRASAKI Y, FUKUNAGA K (2006) Generation of constitutively active calcineurin by calpain contributes to delayed neuronal death following mouse brain ischemia. J Neurochem 98:310-320.

SIMPKINS KL, GUTTMANN RP, DONG Y, CHEN Z, SOKOL S, NEUMAR RW, LYNCH DR (2003) Selective activation induced cleavage of the NR2B subunit by calpain. J Neurosci 23:11322-11331.

SOSA L, DUPRAZ S, LAURINO L, BOLLATI F, BISBAL M, CACERES A, PFENNINGER KH, QUIROGA S (2006) IGF-1 receptor is essential for the establishment of hippocampal neuronal polarity. Nat Neurosci 9:993995.

STRUEWING IT, BARNETT CD, ZHANG W, YADAV S, MAO CD (2007) Frizzled-7 turnover at the plasma membrane is regulated by cell density and the $\mathrm{Ca}(2+)$-dependent protease calpain-1. Exp Cell Res 313:3526 3541

TAHIROVIC S, BRADKE F (2009) Neuronal polarity. Cold Spring Harbor Perspect Biol 1:a001644.

TREMPER-WELLS B, VALLANO ML (2005) Nuclear calpain regulates Ca2+-dependent signaling via proteolysis of nuclear $\mathrm{Ca} 2+/$ calmodulindependent protein kinase type IV in cultured neurons. J Biol Chem 280:2165-2175

TURSUN B, SCHLUTER A, PETERS MA, VIEHWEGER B, OSTENDORFF HP, SOOSAIRAJAH J, DRUNG A, BOSSENZ M, JOHNSEN SA, SCHWEIZER M, BERNARD O, BACH I (2005) The ubiquitin ligase Rnf6 regulates local LIM kinase 1 levels in axonal growth cones. Genes Dev 19:2307-2319.

VOHRA BP, FU M, HEUCKEROTH RO (2007) Protein kinase Czeta and glycogen synthase kinase-3beta control neuronal polarity in developing rodent enteric neurons, whereas SMAD specific E3 ubiquitin protein ligase 1 promotes neurite growth but does not influence polarity. Neurosci 27:9458-9468.

WANG HC, HUANG YS, HO CC, JENG JC, SHIH HM (2009) SUMO modification modulates the activity of calpain-2. Biochem Biophys Res Commun 384:444-449.

WANG HR, ZHANG Y, OZDAMAR B, OGUNJIMI AA, ALEXANDROVA E, THOMSEN GH, WRANA JL (2003) Regulation of cell polarity and protrusion formation by targeting RhoA for degradation. Science 302:1775-1779.

WOODCOCK SA, ROONEY C, LIONTOS M, CONNOLLY Y, ZOUMPOURLIS V, WHETTON AD, GORGOULIS VG, MALLIRI 
A (2009) SRC-induced disassembly of adherens junctions requires localized phosphorylation and degradation of the rac activator tiam1. Mol Cell 33:639-653.

XU W, WONG TP, CHERY N, GAERTNER T, WANG YT, BAUDRY M (2007) Calpain-mediated mGluR1alpha truncation: a key step in excitotoxicity. Neuron 53:399-412.

YAJIMA Y, KAWASHIMA S (2002) Calpain function in the differentiation of mesenchymal stem cells. Biol Chem 383:757-764.

YAMADA M, YOSHIDA Y, MORI D, TAKITOH T, KENGAKU M, UMESHIMA $\mathrm{H}$, TAKAO $\mathrm{K}$, MIYAKAWA T, SATO M, SORIMACHI H, WYNSHAW-BORIS A, HIROTSUNE S (2009). Inhibition of calpain increases LIS1 expression and partially rescues in vivo phenotypes in a mouse model of lissencephaly. Nat Med 15:1202-1207.
YAN D, GUO L, WANG Y (2006) Requirement of dendritic Akt degradation by the ubiquitin-proteasome system for neuronal polarity. J Cell Biol 174:415-424.

YE Y, RAPE M (2009) Building ubiquitin chains: E2 enzymes at work. Nat Rev Mol Cell Biol 10:755-764.

YI JJ, BARNES, AP, HAND R, POLLEUX F, EHLERS MD (2010) TGF-beta signaling specifies axons during brain development. Cell 142:144-157.

YOSHIMURA T, KAWANO Y, ARIMURA N, KAWABATA S, KIKUCHI A KAIBUCHI K (2005) GSK-3beta regulates phosphorylation of CRMP-2 and neuronal polarity. Cell 120:137-149.

ZHOU Y, FANG L, DU D, ZHOU W, FENG X, CHEN J, ZHANG Z, CHEN $Z$ (2008) Proteome identification of binding-partners interacting with cell polarity protein Par3 in Jurkat cells. Acta Biochim Biophys Sin (Shanghai) 40:729-739. 
